\title{
A Decade of Changes in the Transportation of Passengers: What Are the Factors That Affected the Demand?
}

\author{
Francisco Gildemir Ferreira Da Silva ${ }^{1}$ and Sérgio Aquino de Souza ${ }^{2}$ \\ 1. Curso de Finanças-FEAAC, Universidade Federal do Ceará, Vila União CEP: 60410-691, Brazil \\ 2. Curso de Pós-Graduação em Economia, Universidade Federal do Ceará, Segundo Andar, CEP: 60.020-181, Brazil
}

\begin{abstract}
Ten years of financial stability in Brazilian economy have gone. In this period, the regional transportation of passengers suffered exogenous impacts: economical crises, airport crises and great proportions' accidents, as well as impacts which were intern to the system: institutional changes (liberation of tariff promotions, many companies establishing themselves and also coming to bankruptcy), creation of regulating institutions in the air transportation as well as the land transportation. Theoretically, it is expected that these changes have generated impacts in the demand for trips, since an environment regulated with more flexible prices and higher amounts of companies would generate a competitive environment in which the companies could struggle to attract their demand. On the other hand, the impacts which are exogenous to the system can generate responses in the sense of restoring the balance of demand. Thus, based on the theoretical experience, this article aims at analyzing empirically, through categorical variables, if there were impacts on the demand for regional trips in Brazil due to the internal or external changes. In order to perform this, monthly data from January, 1999 to December, 2009 are utilized and estimates are calculated making use of SUR (seemingly unrelated regressions). As a result, we have the meaning of the internal and external impacts related to air and land transports, identifying that the worldwide economic crisis generated an impact at the level of the demand for transportation and also that the flexibility of tariffs allowed by ANTT (Agência Nacional de Transportes Terrestres) had an equal impact on the demand for land transportation.
\end{abstract}

Key words: Seemingly unrelated regressions, passengers transport, demand analysis.

\section{Introduction}

The Coach Interstate Transportation of Passengers (hereafter called TRIP) in long distance travels has been an object of analysis in the international and national studies, aiming at evaluating the factors which cause an impact on the fluxes of demand internal to the countries $[1,2]$. In a general way, these studies aggregate measures about the social economic activities are adopted-population, variation of per capita income, GNP (gross national product), about the services-passengers, seats-kilometers and passengers-kilometers, and about the users-income, age and sex, and some information about the cities of

Corresponding author: Francisco Gildemir Ferreira Da Silva, doctor, research fields: industrial organization, regulation and quantitative methods. departure and arrival.

In the period from 1995 to 2005 , the interstate transportation of passengers in Brazil, both air and land transportation, has been suffering from several changes, especially institutional character which occurred after Brazil regulating mark state in the middle of the 1990s. The highlight was the creation of the ANTT (Agência Nacional de Transportes Terrestres), in 2001 and of the ANAC (Agência Nacional de Aviação Civil), in 2005.

The Passengers Air Transportation (hereafter called TAP) also enabled several studies in the national and international area, starting from the process of reimplementation and flexibility occurred since the beginning of the 1980s [1, 3-6].

Other authors developed compared studies between 
TRIP and TAP, such as Martins et al. [7], who analyzed fluxes of TAP and TRIP passengers in Brazil in the period of 1999 2001, based on concepts of transportation geography, economic and human. Related to the competition between TAP and TRIP, it can occur via prices and/or via quantities, for instance, through diversification of a differentiation of services also called associated attributes, widely explored in the literature $[8,9]$. There are some authors who recently verified the variety in prices of a service in its demand, especially in the case of air transportation [10-13]. However, after 2004, besides the associated attributes, exogenous factors have happened, such as the "air blackout", the worldwide economic crisis and, in Brazil, the liberalization of tax promotions in TRIP. On the other hand, there are few studies which analyze the impact of associated attributes on the competition based on econometric models, considering external or internal facts in relation to the regulatory actions simultaneously.

The objective of this paper is to verify if any impact on the demands for interstate transportation of passengers in Brazil (TRIP and TAP) occurred in the following cases: the enter of the low cost company in air transportation in Brazil from 2000 (GOL air company); the actuation of regulatory agencies (ANTT in 2001 and ANAC in 2005); liberation of tax promotions in 2004; high occurrence of delays and canceling of flights at the end of 2006, known as the "air blackout;" the bankruptcy of the air company VARIG in 2005; economic crisis started in the middle of 2007; and grave air accidents occurred between 2006 and 2010. Methodologically, equations via SUR (seemingly unrelated regression) will be estimated for TRIP and TAP and Dummies will be adopted in order to represent the events described above. These Dummies will be utilized in two ways: as intercept drift and/or as influencing the variation of prices [14]. In the end, the statistical significance of the Dummies will be evaluated in each equation and a joint equation will be estimated with the significant Dummies in the interception and in the variation of prices, obtaining a general equation for all the period of study. The results will be related to the impact of the changes described and to the measurement of the crossed elasticities and inherent to these means of transportation.

The present paper was divided into five sections, taking this introduction into account. The second one concerns the theory which motivated the study, in other words, the economic theory of regulation, the classic theory of the consumer, the seemingly unrelated regressions estimation and the structural breaking point analysis. The third one describes succinctly TRIP and TAP in Brazil, the changes above mentioned and its possible impacts on the means of transportation analyzed. The fourth section applies the methodology and presents the results. Finally, the last section portrays the conclusions of the study.

\section{Theoretical Background}

This theoretical background presents the motivation theory and the analytical tools aspects that will be used in this paper.

\subsection{Economic Theory of Regulation}

The economic theory of regulation indicates possible market failures, such as asymmetry of information, exercise of market power and formation of collusion, which motivate the intervention in transportation markets through governmental actions such as the ones propitiated by regulatory agencies. They work as the model of principal-agent, since they carry out the main role, liberation contracts a trying to impose situations which induce the efficient and competitive action among the regulated companies $[15,16]$. According to the economic literature, the main market failures in the specific case of TRIP and TAP are: oligopolies, asymmetry of information, net industry and external factors.

The asymmetry of information can be understood as being the differences in the information which the 
parts involved in a transaction have, which can be utilized with the purpose of obtaining advantages in the process of decision by one of the interested in the transaction. The availability of insufficient data by the market can harm the process of decision of the user, of the regulator or of the consumer, therefore justifying the intervention of the state in order to guarantee that the information flows in the most efficient way. This can be achieved through the adoption of legislation which induces the market to act transparently [17].

The oligopoly has as its main characteristics [18]: (1) small number of competitors; (2) homogenous or differentiated product, but replaceable; (3) high control under prices, due to the competition between the firms; (4) high extra-price competition due to the concurrence and differentiation; (5) strong barriers to entry; (6) restrictive access to information deriving from competition; (7) maximization of profits or of mark up by the companies; and (8) obtainment of extraordinary long-term profits. The mechanism of formation of prices is influenced by the recognition of the interdependence between the companies, which induces the replacement of the maximization of the companies' individual profit by the maximization of joint profit of the industry [19].

The network industries are characterized by the interoperation among companies and by the integration of different means of service [20]. According to these authors, in the case of TRIP, the state intervention assures that the offer of services results in higher efficiency of the offer and of use, as in the absence of regulation, the operators would compete for the same users, superposing lines and timetables in the most profitable areas, which would cause diseconomies for all system. In other words, there is interdependence between the functions of offer and demand. On the other hand, the higher is the number of users in the service connected to the net, the higher will be the utilization of the same infrastructure, and the offer of a company can influence the offer of other firms.
The external factors are designed as being the effects generated from the welfare to others, which can be positive-when the benefits caused by an activity for another part are not appropriated by the company in charge (e.g., public transportation, investment in sectors of infrastructure), or negative - when an activity brings costs for another part without having the part in charge consider the costs generated (e.g., pollution and traffic jam).

\subsection{Classic Consumer Theory}

The theory of the consumer's behavior supposes that the consumer maximizes its satisfaction when choosing goods and/or services, given their financial restrictions. The function of demand, considered as a relation between the optimal choice (quantities demands) and the different values of prices and income, which can be represented according to the Eq. (1) [21-23]:

$$
Q_{1}=f\left(P_{1}, P_{2}, Y\right)
$$

where:

$Q_{1}$ represents the demand for consumer goods 1;

$P_{1}$ is the price of consumer goods 1 ;

$P_{2}$ is the price of consumer goods 2;

$Y$ is the income of the consumer.

Two approaches are utilized to study the function of demand: the compensed one and the ordinary one. The first one is strictly related to the substitution effect (Hicksian demand) and the second one is related to the income effect (Marshallian demand). In this paper, the approach adopted will be the Marshallian.

Obscure behavior is inherent to the demand due to the idiosyncrasy of the consumer and that can be related to state interventions or strategic actions of competitor companies. That suggests that the demand has an extra component which would be a vector of demands' displacement and which represented every and any variable which influences in the consumer's decision. Thus, Eq. (1) starts to be represented by Eq. (2): 


$$
Q_{1}=f\left(P_{1}, P_{2}, Y, X\right)
$$

where, $\boldsymbol{X}$ is the vector of variables which influences the demand.

The functional form of the demand must be monotonic, concave and strictly increasing in order to possess maximum, serving the Marshallian structure.

The following section is going to present the econometric approach adopted in the paper and the importance of the study. Essentially, estimates of demand with dummies variables of possible demand changes in level and in price coefficients via seemingly unrelated regressions will be made.

\subsection{SUR (Seemingly Unrelated Regressions)}

The SUR (seemingly unrelated regression) is a technique related to estimate equation systems. Its utilization is justified when it is necessary to estimate demands, production or any economic function which involves two economic units which are seemingly unrelated [24]. This kind of regression applies to the article, since apparently, TRIP demands are unrelated to TAP demands.

Roughly speaking, SUR consists of a series of endogenous variables regarded as a group in which there is a strict relation among them. It is carrying out when the assumption of no relation among the equations, such that the disturbances are not correlated there is no validity and, consequently, the estimate for minimum squares is inappropriate. Then, when having correlation among the errors terms, the estimation will only be possible and have good properties via SUR.

The strategy is to join the demand equations making the distinction of observations associated to the first equation and the ones which have relation to the second. Thus, the observations are denominated, randomly attributing the observations 1 to $N$ to the variables from the first equation and $N+1$ to $2 N$ to the variables from the second equation. Observe that the sizes of the samples which are going to be utilized for the equations are the same $N$. Thus, new variables are defined in the following way:

$$
\begin{aligned}
y^{*} & = \begin{cases}y_{1 i} & \text { if } i=1, \ldots, N \\
y_{2 i} & \text { if } i=N+1, \ldots, 2 N\end{cases} \\
x^{*} & = \begin{cases}x_{i} & \text { if } i=1, \ldots, N \\
0 & \text { if } i=N+1, \ldots, 2 N\end{cases} \\
z^{*} & = \begin{cases}0 & \text { if } i=1, \ldots, N \\
z_{i} & \text { if } i=N+1, \ldots, 2 N\end{cases} \\
u^{*} & = \begin{cases}u_{1 i} & \text { if } i=1, \ldots, N \\
u_{2 i} & \text { if } i=N+1, \ldots, 2 N\end{cases} \\
\sigma_{1}^{2} & =\operatorname{Var}\left(u_{1}\right) ; \\
\sigma_{2}^{2} & =\operatorname{Var}\left(u_{2}\right) \text { and } \\
\sigma_{12} & =\operatorname{Var}\left(u_{1}, u_{2}\right)
\end{aligned}
$$

From this specification, Eq. (3) is obtained:

$$
y^{*}=\alpha x *+\beta z^{*}+u^{*}
$$

From this function and applying the technique of the generalized least squares $\alpha$ and $\beta$ are estimates consistently. The advantage is that when having a relation, the variance matrix and the co-variation must present a structure and this structure is put together with the variables which were defined above. The result of a SUR is more general resulting in non-biased and more efficient estimators.

Next, a presentation of the tests of structural break which are going to be utilized in this study will be made, together with the estimates by SUR in order to measure the meaning and the magnitude of the impact on the exogenous and endogenous changes in the market of TAP and TRIP in Brazil.

\subsection{Test of Structural Break}

The statistics theory developed methods in order to test if a function changes from a period to another. Gujarati [25] indicates the Chow test or the variable Dummy approach. There are differences when it comes to the applicability of both methods, being the 
variable Dummy approach the most advantageous for its simplicity according to Table 1 .

The Chow test is a modification of the $F$ generalized test with the difference that this one would serve to measure variations in models with different quantities of variables and that one to test the time stability of standards of the model. This one applies to verify if the standards which measure the interception or the inclination of the function estimate changed through time. In order for this to be analyzed, the null hypothesis is adopted, in which the functions before and after the period in issue to verify the change in behavior are equal. Thus, Eq. (3) can be expressed in the forms of Eqs. (4) and (5):

$$
\begin{aligned}
& Y_{i}=\beta_{1}+\beta_{2} X_{2 i}+\varepsilon_{i} \\
& Y_{j}=\alpha_{1}+\alpha_{2} X_{2 j}+\varepsilon_{j}
\end{aligned}
$$

where, the hypothesis if the parameters are equal is tested:

$$
\alpha_{1}=\beta_{1} ; \alpha_{2}=\beta_{2} ; \ldots ; \text { and } \alpha_{k}=\beta_{k}
$$

In case the hypothesis does not occur in the parameter of index 1, the functions are different in the interception, but the inclinations are the same, thus, parallel. In case of the difference occur in other coefficients, the inclination of the line or of the hyperplane is the one who is harmed. It may also occur the fact that the functions have all the differentiated coefficients, being, thus, completely different.

The approach of the Dummy variable applies, as well as the Chow test, in the identification of change in behavior of an estimated function via econometric methods. In this approach a Dummy is inserted for the interception and another one for the inclination standard. With this specification, Eqs. (4) and (5) are converted in Eq. (6):

$$
Y_{j}=\alpha_{1}+\alpha_{2} D_{j}+\beta_{1} X_{j}+\beta_{2}\left(D_{j} X_{j}\right)+\varepsilon_{j}
$$

Next, the coefficients of the Dummies variables are tested in order to see if they are significant. Since one of the econometric principles is the expectancy of the error to be zero, it might be expected that the situations are represented by Eqs. (7) and (8):

$$
\begin{gathered}
E\left(Y_{j} / D_{j}=0, X_{j}\right)=\alpha_{1}+\beta_{1} X_{j} \\
E\left(Y_{j} / D_{j}=1, X_{j}\right)=\left(\alpha_{1}+\alpha_{2}\right)+\left(\beta_{1}+\beta_{2}\right) X_{j}(8)
\end{gathered}
$$

\section{Passenger Transport}

This section presents the characteristics of passenger transport in Brazil, dividing it between air and coach interstate passengers transport.

\subsection{Coach Interstate Passenger Transport-TRIP}

With the change of Act 10.233 [26], the ANTT was created, whose main objectives in relation to providing TRIP services in Brazil are: to edit rules and guidelines; to promote study on prices and taxes; to elaborate studies on technical, economic and financial viability, to check readjust and revision of taxes/fares; to publish official procurements and provide contracts to services operation.

The regulatory actions of ANTT started in February 2002, when its statute was approved. From this time on, the agency started to regulate and to inspect TRIP services, task that the Ministry of Transportation used

\begin{tabular}{|c|c|c|}
\hline & Chow test & Dummy variables approach \\
\hline Number of equations & 2 & 1 \\
\hline Number of tests & Many, but for each regression & Many, but for consequently only one equation \\
\hline Efficacy in the analysis & It does not reveal explicitly which standard is different & It informs precisely which one is the different standard \\
\hline $\begin{array}{l}\text { Quality of the } \\
\text { estimation }\end{array}$ & $\begin{array}{l}\text { Since they are two equations, many degrees of freedom } \\
\text { are lost, which, therefore, might harm the estimate }\end{array}$ & $\begin{array}{l}\text { Since only one equation is utilized, less degrees of } \\
\text { freedom are lost, which implies in a more precise } \\
\text { estimate }\end{array}$ \\
\hline
\end{tabular}
to let the private initiative perform, putting into practice the guidelines of the legislation of that period, specially Law 8.987 [27] and Decree 2.521 [28].

The quality of the TRIP service has not been object

Table 1 Comparison between the Chow test and the Dummy variables approach. 
of profound regulation by the ANTT, mainly the establishment of operational parameters that try to show productivity of the service, such as: bus-kilometer average annual-PMA, use index-IAP, order reduction factor-FRE, and average fleet capacity-LOT. Yet, another factor should be considered: there are some bus lines that are too long, with more than $2.000 \mathrm{~km}$, which can result in discomfort, high costs and the use of lines to the creation of informal markets, among other aspects.

When it comes to TRIP, many studies have analyzed the point of concentration of service offer in a national and international perspective [29-41,] trying to identify impacts on price and quality of the service offered.

\subsection{TAP (Air Passenger Transport)}

The TAP, together with TRIP, is part of the SNV (Sistema Nacional de Viação), which is defined by Act 5.917 [42], with the changes of Act 6.261 [43], emphasizing the need for promotion of the regional and geopolitical integration of Brazil.

Concerning the SNV, the infrastructure and the structure of air operation are defined by the principles of safety, regularity and protection to air navigation, highlighting airports, which constitute the SNV. The regulation of air transportation in Brazil, before the creation of ANAC by means of Law 11.182 [44], is greatly influenced by international organs, such as: International Civil Aviation Organization-ICAO; Air Transport Association-IATA; Airports Council International; Federal Aviation Administration-FAA.

Many studies regarding TAP have analyzed the concentration of service offer in a national and international scenario, such as Gonene and Nicoletti [45]. The concentration has to do with the beginning of the civil aviation, and cooperation came up with the code-share. The processes of concentration and cooperation were intensified due to authorization of air transportation, which occurred around 1990 in Brazil, after the global influence of the American market back in 1970 .

Recently, the regular air transportation of passengers in Brazil has suffered some changes in its systemic operation. Many successful companies went bankrupt (TRANSBRASIL, VASP and VARIG) and new companies aiming at providing popular tickets appeared, such as GOL. According to Martins and Danni [46], it is a market that operates under the private logic, with increasing competition levels, which has been proved very interesting not only for passengers, but also for the whole market.

The financial crises observed in the air transportation market, according to recent literature, are due to their pro-cyclic characteristics and the necessary period for the consolidation of investments. According to Martins and Danni [46], in the Brazilian air market, the current structure and the operational drawbacks of the companies, the increase in the competition level in the market, the varieties of the products, and the dynamics of the demands, require a high flexibility to allocate the quantity of flights provided by the companies. On the other hand, the authors assert that there is a high technical and security regulation implemented, as well as levels of continuity and quality of services, which can be applied without using the legislation of concessions.

The remove of barriers to entry and the TRIP politics fares in Brazil can intensify the operational dynamics in these services, in a way to increase the competition among TAP. Being so, the competition between TRIP and TAP is all about providing high quality services. That would help the user to choose TRIP instead of TAP, considering not only price as a decision factor, as Martins et al. [47] identified, but also the quality of the service.

\section{Methodology, Models and Empirical Results}

\subsection{Description of the Methodology and the Equations Studied}

Methodologically, the system of equations related 
to Eqs. (7) and (8) will be used, which will serve to verify if the level of changes occurs, considering the existence of one of the endogenous or exogenous impacts that we aim at estimating:

$$
\begin{aligned}
& D_{\text {air }}=\beta_{0}+\beta_{1} I P C A_{\text {air }}+\beta_{2} I P C A_{\text {road }}+\beta_{3} \text { realwage }+\beta_{i} \text { DummiesAir }+\varepsilon \\
& D_{\text {road }}=\alpha_{0}+\alpha_{1} I P C A_{\text {air }}+\alpha_{2} I P C A_{\text {road }}+\alpha_{3} \text { realwage }+\alpha_{i} \text { DummiesRoad }+\mu
\end{aligned}
$$

where, $D_{\text {air }}$ represents the demand for the TAP services;

$D_{\text {road }}$ represents the demand for the TRIP services;

$\beta_{0}$ and $\alpha_{0}$ are interceptors of the equations;

$\beta_{i}$ represents the parameters of the variables of the demand for the TAP services to $i=1,2$ and 3;

$\alpha_{i}$ represent the parameters of the variables of the demand for the TRIP services to $i=1,2$ and 3;

$I P C A_{\text {air }}$ is a proxy of the TAP charges, considering that IPCA stands for índice de preços ao consumidor amplo (extended national consumer price index), extremely used for readjusting prices in Brazil as index to measure inflation;

$I P C A_{\text {road }}$ is a proxy of the TRIP services;

Realwage is a proxy of the service user's income;
DummiesAir is a matrix of categorical variables that indicate the entrance of GOL Company, the crisis on VARIG, the sales on air tickets by the Conselho Administrativo de Defesa Economica-CADE, the "air blackout", accidents with airplanes, worldwide economic crisis and the influence of ANAC;

DummiesRoad consists of a matrix of categorical variables that indicate the action of ANTT, sales in the TRIP charges;

$\varepsilon$ and $\mu$ represent the errors-term.

After that, considering Eqs. (11) and (12), it will be verified if changes on the demand for changes by the increase of prices of the road or air means of transportation by bus occurred.

$$
\begin{gathered}
D_{\text {air }}=\beta_{0}+\beta_{1} I P C A_{\text {air }}+\beta_{2} I P C A_{\text {road }}+\beta_{3} \text { realwage }+\beta_{i} \text { DummiesAair } * I P C A_{\text {aair }}+\varepsilon \\
D_{\text {road }}=\alpha_{0}+\alpha_{1} I P C A_{\text {air }}+\alpha_{2} I P C A_{\text {road }}+\alpha_{3} \text { realwage }+\alpha_{i} \text { DummiesRoad } * I P C A_{\text {road }}+\mu
\end{gathered}
$$

where, the variables follow the same description of Eqs. (9) and (10).

When the source of impacts is identified and, if it was related to the interceptor and/or the raise of prices, the last system of equations will be estimated as follows (Eqs. (13) and (14)):

$$
\begin{aligned}
D_{\text {air }}= & \beta_{0}+\beta_{1} I P C A_{\text {air }}+\beta_{2} I P C A_{\text {road }}+\beta_{3} \text { realwage }+\beta_{i} \text { DummiesAir }^{*} I P C A_{\text {air }}+ \\
\text { DummiesAir }+\varepsilon & \\
& D_{\text {road }}=\alpha_{0}+\alpha_{1} I P C A_{\text {air }}+\alpha_{2} I P C A_{\text {road }}+\alpha_{3} \text { realwage }+\alpha_{i} \text { DummiesRoad }^{*} I P C A_{\text {road }}+ \\
& \text { DummiesRoad }+\mu
\end{aligned}
$$

The verification of relevance of the categorical variables is done by using the statistics analysis $t$ and the $p$ value of the dummies after the estimate. In Eqs. (13) and (14), the categorical variables used are the ones who were considered relevant from the Eqs. (9) to (12).

\subsection{Data Description and Descriptive Statistics}

Data used for modeling were acquired on the websites of the following institutions: IPEADATA (wage), Instituto de Pesquisa Economica Aplicada-IPEA, Instituto Brasileiro de Geografia e Estatística-IBGE (IPCAair and IPCAroad), and Fundação Instituto de Pesquisas Econômicas-FIPE $D_{\text {air }}$ and $D_{\text {road }}$ ). 133 monthly observations were totaled from January, 1999 to December, 2009. A seasonality adjust in the TRIP was made by means of a Dummy variable for the vacation period, which was presented 
in Bussab and Morettin [48].

In the process of modeling, the difference of the demand for TAP and for TRIP was used. This difference was used as hypothesis that there is answer as to the road transportation using buses even with the changes on air transportation. The supposition mentioned above is based on Da Silva et. al. [11]. Moreover, as a tendency in the series was observed, it was supposed that there was a deterministic tendency and the regression using time as one of the variables $[24,25]$. Table 2 presents the describing statistics of the database variables, considered as index numbers related to January, 1999. It can be observed in the standard deviation that the volatility of the demands is similar. However, the prices indicated a bigger volatility for the TRIP price, but with negative averages and medians only for the TAP price, probably due to a high concurrence in this modality.

The categorical variables were analyzed based on information obtained as follows:

- $d$ 50: ticket sales in the TAP (date informed by CADE authorizing $\mathrm{R} \$ 50.00$ tickets of the GOL company);

- $d$ acid: accident of the GOL company airplane (in 09/29/2006 with 154 deaths), accident of the TAM company airplane (in 07/17/2007 with 1,999 deaths) and accident with the Air France company airplane (in 11/30/2009 with 288 deaths) (data obtained on the website $^{1}$ ), it was considered ad_hoc that the accidents presented will stay for six months in the people's minds, because studies on the time of impact of the accidents on demand were not found;

- $d_{-} A N A C$ : beginning of activities of ANAC, described on the text above;

- d_ANTT: variable before ANTT;

- d_apag: obtained on a cut line to provide the variable dummy under the index of punctuality (higher than $50 \%$ of punctuality loss) and delays (no more than 20\%), obtained on the ANAC website;

- d_ent_GOL: date of the beginning of operation

\footnotetext{
${ }^{1} \mathrm{http}: / /$ www.desastresaereos.net/acidentes_brasil_06.htm.
}

of GOL company (obtained on the regularity, punctuality and efficiency indexes on the ANAC website);

- d_flex_rod: date of homologation of the Resolution 2.920 [49], authorizing ticket sales in the TRIP;

- $d_{-} V A R I G$ : date of the beginning of crisis on VARIG company, which ended up in the acquisition of this company by the GOL company (obtained on Folha de Sao Paulo, Veja, Conjuntura Contabil and Senado Nacional websites);

- d_saz: assumed ad hoc, which means the seasonality for the road transportation (in January, February, July and December); and

- $d$ crise: date of the beginning of worldwide economical crisis, considered to start in October, 2007, according to research on national newspapers and magazines).

\subsection{Results of the Models}

This item presents the results of the models in TAP and in TRIP on Tables 3 and 4, respectively. The sequence obeys the methodology presented in the two previous models, impact on the interceptor and impact on the price of each means of transportation, in Table 3, and model of conjunct impacts on Table 4, where the field Prob. indicates the $p$ value corresponding to the respective coefficient. The meanings of the variables have been mentioned on the previous equations and tables of this article.

According to the methodology, the impacts of the interception on the demand by TAP were due to the interference of ANAC, the air accidents and the worldwide economical crisis, but the latter contributed to the increase on the prices, together with the crisis on VARIG Company. The impacts on TRIP were due to the fare politics of the charges and only on the intercept of the demand. After that, the estimates of the conjunct model were done, and presented in Table 5.

According to the results obtained, the accidents and 
A Decade of Changes in the Transportation of Passengers:

What Are the Factors that Affected the Demand?

Table 2 Descriptive statistics of continual data of the database.

\begin{tabular}{llllll}
\hline & $D E M \_A R \_I N D$ & $D E M \_R O D \_I N D$ & $I P C A \_A R \_I N D$ & $I P C A \_R O D \_I N D$ & $S A L \_M \_I N D$ \\
\hline Average & 0.5494 & 0.8665 & -0.3492 & 0.6002 & 0.5381 \\
Median & 0.4876 & 0.8221 & -0.0325 & 0.0226 & 0.5098 \\
Std. dev. & 0.1504 & 0.1437 & 1.3620 & 1.8172 & 0.2117 \\
N. of Obs. & 133 & 133 & 133 & 133 & 133 \\
\hline
\end{tabular}

Notes: $D E M \_A R \_I N D$ represents the index of demand for TAP services;

$D E M \quad R O D O I N D$ represents the index of demand for TRIP services;

$D E M \_A R \_I N D$ represents the index of demand for TAP services;

$I P C A \_A R \_I N D$ represents the index of IPCA for the TAP services;

$I P C A \_R O D \_I N D$ represents the index of IPCA for TRIP services;

$S A L \_M \_I N D$ represents the index of the minimum wage.

Table 3 Models of effects of the intercept and effects of price for each model with its statistics in the TAP.

\begin{tabular}{lllll}
\hline \multicolumn{2}{l}{ Effect in the intercept on the demand for the TAP } & \multicolumn{1}{c}{ Effect on the price of the air transportation on the demand for the TAP } \\
\hline Variables & Coefficients & Prob. & Coefficients & Prob. \\
\hline Constants & 33.70630 & 0.1028 & 63.79625 & 0.0001 \\
IPCA_AR_IND & -0.007666 & 0.0050 & 0.003143 & 0.7652 \\
IPCA_ROD_IND & 0.007568 & 0.0002 & 0.006420 & 0.0045 \\
SAL_M_IND & 0.684723 & 0.0000 & 1.138135 & 0.0000 \\
D_ANAC & 0.035947 & 0.0756 & 0.038148 & 0.3314 \\
D_APAG & 0.016685 & 0.2450 & 0.036780 & 0.6164 \\
D_VARIG & 0.007171 & 0.6312 & -0.051347 & 0.0858 \\
$T$ & $-4.59 \mathrm{E}-05$ & 0.1055 & $-8.73 \mathrm{E}-05$ & 0.0001 \\
$D_{-} 50$ & 0.002917 & 0.8716 & 0.011969 & 0.6748 \\
D_ACID & 0.024721 & 0.0707 & 0.011916 & 0.1185 \\
D_ENT_GOL & -0.003030 & 0.8689 & -0.011952 & 0.3288 \\
D_CRISE & 0.087010 & 0.0000 & -0.053289 & 0.0523 \\
$R^{2}$ & 0.921569 & & 0.903670 & \\
$R^{2}$ ajustado & 0.914438 & & 0.894913 & \\
\hline
\end{tabular}

Table 4 Models of effects of the interception and effects of price for each model with its statistics in TRIP.

\begin{tabular}{|c|c|c|c|c|}
\hline \multicolumn{3}{|c|}{ Effect in the intercept on the demand for the TAP } & \multicolumn{2}{|c|}{ Effect on the price of the air transportation on the demand for the TAP } \\
\hline Variables & Coefficients & Variables & Coefficients & Variables \\
\hline Constants & 111.8081 & 0.0037 & 87.17364 & 0.0220 \\
\hline$I P C A \_A R \_I N D$ & -0.005566 & 0.2752 & -0.005192 & 0.4334 \\
\hline$I P C A \_R O D \_I N D$ & -0.003928 & 0.3494 & 0.017906 & 0.4632 \\
\hline$S A L \_M \_I N D$ & 0.484602 & 0.0832 & 0.390150 & 0.1550 \\
\hline$D \_S A Z \_R O D$ & 0.147092 & 0.0000 & 0.017726 & 0.1372 \\
\hline$T$ & -0.000152 & 0.0040 & -0.000119 & 0.0231 \\
\hline$D E M \_R O D \_I N D(-2)$ & 0.194573 & 0.0020 & 0.271432 & 0.0006 \\
\hline$D \_A N T T$ & -0.038228 & 0.2101 & -0.027031 & 0.2395 \\
\hline$D \_F L E X \_R O D$ & 0.061332 & 0.0427 & 0.017393 & 0.1535 \\
\hline$R^{2}$ & 0.674887 & & 0.449589 & \\
\hline$R^{2}$ ajustado & 0.653568 & & 0.413496 & \\
\hline
\end{tabular}


Table 5 Model of the conjunct effects on intercept and price.

\begin{tabular}{|c|c|c|c|c|c|}
\hline \multicolumn{3}{|c|}{ Effect in the intercept on the demand for the TAP } & \multicolumn{3}{|c|}{ Effect on the price of the air transportation on the demand for the TAP } \\
\hline Variables & Coefficients & Variables & Coefficients & Variables & Variables \\
\hline Constants & 35.09363 & 0.0125 & Constante & 141.1374 & 0.0000 \\
\hline$I P C A \_A R \_I N D$ & -0.000476 & 0.9289 & $I P C A \_A R \_I N D$ & -0.005484 & 0.2843 \\
\hline$I P C A \_R O D \_I N D$ & 0.007425 & 0.0002 & $I P C A \_R O D \_I N D$ & -0.005021 & 0.2274 \\
\hline SAL_M_IND & 0.690057 & 0.0000 & $S A L \_M \_I N D$ & 0.658536 & 0.0087 \\
\hline$D \_A N A C$ & 0.042948 & 0.0030 & $D \_S A Z \_R O D$ & 0.151489 & 0.0000 \\
\hline$T$ & $-4.78 \mathrm{E}-05$ & 0.0132 & $T$ & -0.000192 & 0.0000 \\
\hline$D \_A C I D$ & 0.035435 & 0.0017 & $D E M \_R O D \_I N D(-2)$ & 0.198656 & 0.0019 \\
\hline D_CRISE & 0.077044 & 0.0000 & $D \_F L E X \_R O D$ & 0.065165 & 0.0261 \\
\hline D_ACID_PRECO & 0.013026 & 0.0579 & & & \\
\hline D_CRISE_PRECO & -0.012832 & 0.0408 & & & \\
\hline D_VARIG_PRECO & -0.004346 & 0.7225 & & & \\
\hline$R^{2}$ & 0.926215 & & $R^{2}$ & 0.671898 & \\
\hline$R^{2}$ ajustado & 0.920167 & & $R^{2}$ ajustado & 0.653226 & \\
\hline
\end{tabular}

the worldwide crisis presented effects on the prices of the intercept and the demand for TAP. The homologation of the Resolution 2.920 [49] by the ANTT had effect on the intercept of the demand for TRIP.

Besides, it is believed that the actions of ANTT did not generate impacts per si on the demand for road transportation. Concomitantly, the entrance of GOL Company, the sales on air tickets, the "air blackout" and the crisis on VARIG did not have effect on the demand for air transportation. This fact corroborates the decision of ANAC and CADE of authorizing sales on air tickets, and GOL did not contribute for higher competition on air transportation. It also indicates that the demand of VARIG, with its crisis, was probably absolved by the other companies. In the viewpoint of exogenous shock, as the "air blackout", it was observed that it did not affect the demand for air transportation, possibly because of the past few years, and maybe it minimized due to the entrance of GOL Company in the "air blackout", which indicates the necessity of further studies.

\section{Conclusions}

Through the application of the model presented, it was possible to verify that not only the regulatory impacts but also the exogenous impacts generated changes in the behavior of the demand in both models of transportation of passengers.

In TAP, the impacts in level of the calculated hyperplane which defines the function of demand were originated from the entrance of operation of the ANAC, from the air accidents and from the worldwide economic crisis, but the last two ones also provoked an impact on the price of air transportation, in other words, in the inclination of the hyperplane. It must be also observed that the most significant impact for variables adopted in the proposed model was the economic crisis in the level of demand, being approximately $8 \%$ positive, indicating an increase in the use of air transportation, being coherent since the price suffered a decrease due to the crisis. However, curiously, the impact of the accidents was positive not only in level of demand as in the inclination of the price of air transportation.

On the other hand, TRIP suffered an impact mainly through the effects of seasonality and of the regulatory action of making the market tariffs flexible, considering the fact that ANTT exists. Impacts on the advent of ANTT in the operation of road transportation were not detected maybe due to the fact that there is not any advent of operator or strong intervention in the market after the entrance of ANTT, on the contrary of what happened in the air market 
with the entrance of the low cost companies. The same methodology could also be applied with the data of the transportation of load for the different means of transportation.

\section{References}

[1] Rus, G., and Campos, J. 2001. El Sistema de Transporte Europeo: Un Análisis Económico. Espanha: Editora Síntesis. (in Portuguese)

[2] OECD. 2001. Ecmt Round Tables Regular Interurban Coach Services in Europe: No. 114 (Paperback). Organization for Economic Co-Operation and Development. Paris.

[3] Morrison, S. A., and Winston, C. 1985. "Intercity Transportation Route Structures Under Deregulation: Some Assessments Motivated by the Airline Experience." The American Economic Review 75 (2).

[4] Guimarães, E. A., and Salgado, L. H. 2003. A Regulação do Mercado de Aviação Civil no Brasil. Notas Técnicas 2. Rio de Janeiro: Instituto de Pesquisa Econômica Aplicada IPEA. (in Portuguese)

[5] Oliveira, A. V. M. 2005. The Impacts of Liberalization on Competition on an Air Shuttle Market. Documento de Trabalho No. 006. São José dos Campos, SP. Accessed June 5, 2008. www.ita.br/ nectar.

[6] Ragazzo, C. A. E. 2006. O Processo de Flexibilização e as Fusões e os Acordos de Cooperação no Mercado de Transporte Aéreo de Passageiros. Documento de Trabalho No. 32. Accessed July 5, 2007. www.seae.fazenda.gov.br. (in Portuguese)

[7] Martins, F. G. D.,. Rocha, C. H., and Da Silva, F. G. F. 2008. "Uma Análise Sobre Fluxos de Passageiros de Transporte Aéreo e Rodoviário Interestadual por Ônibus no Brasil." Presented at Anais do XXII Congresso de Pesquisa e Ensino em Transportes. XXII ANPET, Fortaleza. (in Portuguese)

[8] Oum T. H., Waters W. G., and Yong J. S. 1992. "Concepts of Price Elasticities of Transport Demand and Recent Empirical Estimates: An Interpretative Study." Journal of Transport Economics and Policy 26 (2): 139-54.

[9] Turolla, F. A., Vasallo, M. D., and Oliveira, A. V. M. 2005. "Inter-Modal Competition in The Braziliam Interstate Travel Market." Presented at the 9th International Conference on Competition and Ownership in Land Passenger Transport, Lisboa.

[10] Tavares, M. P. 1999. O Transporte Aéreo Doméstico e a Lógica da Desregulamentação. Secretaria de Acompanhamento Econômico/Ministério da Fazenda-SEAE/MF. Documento de Trabalho No. 04. (in Portuguese)
[11] Da Silva, F. G. F., Rocha; C. H., and Martins, F. G. D. 2009. "Modelagem Econométrica para Averiguar o Efeito Substituição do Transporte Rodoviario Interestadual de Passageiros por Ônibus pelo Transporte Aéreo." Presented at Simpósio Brasileiro de Transporte Aéreo-SITRAER 2009, São Paulo. (in Portuguese)

[12] Franco, F. A. L., Santana, P. M., Almeida, C. B., and Braga, R. J. 2002. Recent Deregulation of the Air Transportation in Brazil-Secretaria de Acompanhamento Econômico/Ministério da Fazenda-SEAE/MF. Documento de Trabalho No. 12. (in Portuguese)

[13] Oliveira, A. V. M. 2004. "Estimation of a Model of Low Cost Carrier Entry." Presented at ESRC Econometric Study Group-Annual Conference.

[14] Da Silva, F. G. F., Valim, F. C., Prado, M. V., and Yamashita, Y. 2007. "A Eficência Operacional do Transporte Aéreo de Pessoas no Brasil foi Comprometida pelas Empresas Low Cost? Estudo Empirico do Fenômeno." Presented at Simpósio Brasileiro de Transporte Aéreo-SITRAER 2007, Rio de Janeiro. (in Portuguese)

[15] Tirole, J. 1988. The Theory of Industrial Organization. Cambridge, Massachusetts, Londres. Inglaterra: The MIT Press.

[16] Viscusi, W. K., Vernon, J. M., and Harrington, J. E. 2000. Economics of Regulation and Antitrust. 3rd ed. Cambridge, Massachusetts, Londres, Inglaterra: The MIT Press.

[17] Giambiagi, F., and Além, A. C. 2000. Finanças Públicas: Teoria e Prática no Brasil. 2nd ed. Rio de Janeiro: Campus. (in Portuguese)

[18] Rossetti, J. P. 2003. Introdução à Economia. 20th ed. São Paulo: Editora Atlas. (in Portuguese)

[19] Garófalo, G. L., and Carvalho, L. C. P. 1992. Teoria Econômica. 2nd ed. São Paulo: Editora Atlas. (in Portuguese)

[20] Gomide, A. A., and Martins, F. G. D. 2005. "Regulation of the Interstate and International Highway System for the Transportation of Passengers: Suggestions for a Competitive Agenda." Presented at 9th International Conference on Competition and Ownership in Land Passenger Transport, Lisboa.

[21] Varian, H. R. 2003. Microeconomia: Princípios Básicos; Uma Abordagem Moderna. 6th ed. Rio de Janeiro: Campus. (in Portuguese)

[22] Ferguson, C. E. 1999. Microeconomia. 20th ed. Rio de Janeiro: Forense Universitária. (in Portuguese)

[23] Henderson, J. M., and Quandt, R. E. 1976. Teoria Microeconômica: Uma Abordagem Matemática. São Paulo: Biblioteca Pioneira de Ciências Sociais. (in Portuguese) 
[24] Pindyck, R. S., and Rubinfeld, D. L. 2004. Econometria: Modelos e Previsões. Rio de Janeiro: Elsevier. (in Portuguese)

[25] Gujarati, D. N. 2000. Econometria Básica. 3rd ed. São Paulo: Makron Books. (in Portuguese)

[26] Brazil. 2001. Lei 10.233, de 5 de Junho de 2001. Dispõe Sobre a Reestruturação dos Transportes Aquaviário e Terrestre, cria o Conselho Nacional de Integração de Políticas de Transporte, a Agência Nacional de Transportes Terrestres, a Agência Nacional de Transportes Aquaviários e o Departamento Nacional de Infra-Estrutura de Transportes, e dá outras providências. Brasília. Accessed June 25, 2010. http://www.senado.gov.br. (in Portuguese)

[27] Brazil. 1995. Lei 8.987, de 13 de Fevereiro de 1995. Dispõe sobre o Regime de Concessão e Permissão da Prestação de Serviços Públicos Previsto no Artigo 175 da Constituição Federal, e dá Outras Providências. Brasília. Accessed June 25, 2010. http://www.senado.gov.br. (in Portuguese)

[28] Brazil. 1998. Decreto 2.521, de 20 de Março de 1998. Dispõe Sobre a Exploração, Mediante Permissão e Autorização, de Serviços de Transporte Rodoviário Interestadual e Internacional Coletivo de Passageiros e dá Outras Providências. Brasília. Accessed June 25, 2010. http://www.senado.gov.br. (in Portuguese)

[29] Mundial, B. 1999. Impact and Benefits of Deregulation. Accessed June 25, 2010. http://www.worldbank.org.

[30] McCarthy, P. 2001. Transportation Economics. Massachusetts: Blackwell.

[31] Martins, F. G. D. 2004. Transporte Rodoviário Interestadual e Internacional de Passageiros: Regulação e Concentração Econômica. Monografia (Especialização em Controle da Regulação de Serviços Públicos Concedidos)-Tribunal de Contas da União, Instituto Serzedello Corrêa. $160 \mathrm{f}$. Brasília. (in Portuguese)

[32] MT and MD. 2007. Plano Nacional de Logística e Transportes: Relatório Executivo. Ministério dos Transportes e Ministério da Defesa. Accessed June 7, 2008. http://www.centran.eb.br/plano_logistica.htm. (in Portuguese)

[33] Müller, A. 2003. "Regulatory Reform in Intercity Bus Transportation: Impacts and Issues." Buenos Aires University. Argentina.

[34] Rocha, C. H., Martins, F. G. D., and Machado, T. M. 2005. "Brazilian Interstate Passenger Transportation Industry: concentration and returns." Presented at 9th International Conference on Competition and Ownership in Land Passenger Transport, THREDBO 9, Lisboa.

[35] Santos, E. M., and Martins, F. G. D. 2006. "Regulamentação e Territorialidade da Concentração Industrial no Mercado de Ônibus Interestaduais no
Brasil." Presented at Anais do XIV Congresso Panamericano de Transportes. Isla Canárias, Espanha.

[36] Wright, C. 1992. Transporte Rodoviário de Ônibus. Brasília: Instituto de Pesquisa Econômica Aplicada-IPEA. (in Portuguese)

[37] White, P. 1995. "Deregulation of Local Buses Services in Great Britain: An Introductory Review." Transport Reviews 15 (2): 185-209.

[38] Martins, F. G. D., Rocha, C. H., and Barros, A. P. B. G. 2004. "Concentração na Indústria de Transporte Rodoviário Interestadual e Internacional de Passageiros." Presented at Anais do XVIII Congresso de Ensino e Pesquisa em Transportes. XVIII ANPET. Florianópolis. (in Portuguese)

[39] Santos, E. M. 2000. "Concentração em Mercados de Ônibus no Brasil: Uma Análise do Papel da Regulamentação.” Ph.D. thesis, Universidade Federal do Rio de Janeiro. (in Portuguese)

[40] White, P. 1999. "What Conclusions Can Be Drawn about Bus Deregulation in Britain?." Transport Reviews 17 (1): 1-16.

[41] Orrico Filho, R. D., and Santos, E. M. 1996. "Transporte Coletivo Urbano por Ônibus: Regulamentação e Competição." In Onibus Urbano: Regulamentação e Mercados, edited by Orrico Filho, R. D. et. al. Brasília: LGE. (in Portuguese)

[42] Brazil. 1973. Lei 5.917, de 10 de Setembro de 1973. Aprova o Plano Nacional de Viação e dá Outras Providências. Brasília. Accessed June 25, 2010. http://www.senado.gov.br. (in Portuguese)

[43] Brazil. 1975. Lei 6.261, de 14 de Novembro de 1975. Dispõe Sobre o Sistema Nacional dos Transportes Urbanos, Autoriza a Criação da Empresa Brasileira dos Transportes Urbanos e dá Outras Providências. Brasília. Accessed June 25, 2010. http://www.senado.gov.br. (in Portuguese)

[44] Brazil. 2005. Lei 11.182, de 27 de Setembro de 2005. Cria a Agência Nacional de Aviação Civil-ANAC, e dá Outras Providências. Accessed June 25, 2010. http://www.senado.gov.br. (in Portuguese)

[45] Gonene, R., and Nicoletti, G. 2000. "Regulation, Market Structure and Performance in Air Passenger Transportation." OECDE. Economic Department. Working Paper No. 254.

[46] Martins, F. G. D., and Danni, L. S. 2008. "Uma Análise Sobre a Dinâmica Operacional na Prestação de Serviços de Transporte Aéreo Regular de Passageiros no Brasil." Presented at Anais do XXII Congresso de Pesquisa e Ensino em Transportes. XXII ANPET, Fortaleza. (in Portuguese)

[47] Martins, F. G. D., Da Silva, F. G. F., and Rocha, C. H. 2006. "Uma Análise de Fatores Determinantes das Condições de Concorrência nos Mercados de Transporte 
A Decade of Changes in the Transportation of Passengers:

What Are the Factors that Affected the Demand?

Rodoviário Interestadual de Passageiros." In Anais do $X X$ Congresso de Pesquisa e Ensino em Transportes. XX ANPET-Kaco Gráfica e Editora, 940-51. (in Portuguese)

[48] Bussab, W. O., and Morettin, P. A. 2002. Estatística Básica. São Paulo: Saraiva. (in Portuguese)

[49] ANTT. 2008. Resolução 2.920, de 10 de Outubro de
2008. Autoriza a Abertura de Consulta Pública Objetivando Obter Contribuições para Elaboração do ProPass Brasil-Projeto da Rede Nacional de Transporte Rodoviário Interestadual de Passageiros. Agência Nacional de Transporte Terrestres. Accessed July 23，2009. http://www.antt.gov.br/acpublicas/ CPublica2008-01/resolucao_cp001.pdf. (in Portuguese) 